Article

\title{
Urban Space and Gender Performativity in Knut Hamsun's Hunger and Cora Sandel's Alberta and Freedom
}

\author{
Unni Langås \\ Department of Nordic and Media Studies, University of Agder, 4604 Kristiansand, Norway; unni.langas@uia.no \\ Received: 30 September 2018; Accepted: 1 December 2018; Published: 4 December 2018

\begin{abstract}
In this article, I discuss the combination of city life and gender performativity in two Norwegian classics, Knut Hamsun's Hunger (2016) [Sult, 1890] and Cora Sandel's Alberta and Freedom (1984) [Alberte og friheten, 1931]. These are modernist novels depicting lonely human subjects in an urban space, the first one featuring a man in Kristiania (now Oslo) in the 1880s, the second one a woman and her female acquaintances in Paris in the 1920s. I interpret and compare the two novels by focusing on their intertwined construction of gender performativity and urban space. Gender norms of the city life are critical premises for how the subjects manage to negotiate with different options and obstacles through their modern existences. To both protagonists, inferior femininity is a constant option and threat, but their responses and actions are different. The strategy of the male subject in Hunger is to fight his way up from humiliation by humiliating the female other; the strategy of the female subject in Alberta and Freedom is instead to seek solidarity with persons who have experiences similar to her own. Hamsun's man and Sandel's woman both perceive their own bodies as crucial to the interpretation of their physical surroundings. However, while the hero in Hunger must deal with a body falling apart and a confrontation with the world that depends on a totally fragmented bodily experience, the heroine in Alberta and Freedom instead sees herself as a body divided between outer appearance and inner inclinations. Both novels stage a person with writing proclivities in a city setting where the success or failure of artistic work is subjected to the mechanisms of a market economy. Their artistic ambitions are to a large extent decided by their material conditions, which seem to manipulate Hamsun's hero out of the whole business, and Sandel's heroine to stay calm and not give up. Yet the novels share the belief in the body's basis as a denominator for the perception and interpretation of sensual and cognitive impressions of the world.
\end{abstract}

Keywords: urban space; gender performativity; Hamsun's Hunger; Sandel's Alberta and Freedom; modern metropolis; streetwalking

\section{Introduction}

Closely tied to the development of modernist literature is the growing urbanisation and new lifestyles in metropolitan areas. Modernist classics, like James Joyce's Ulysses (Joyce [1924] 1972) and Virginia Woolf's Mrs. Dalloway (Woolf [1925] 2000), are interpretations of human life in a city characterised by rapid expansion and technological innovations. Commonly, modernist literature is seen as a response to the dual aspects of modernity, exploring on the one hand its promising industrial achievements and on the other its more shadowy effects of alienation and rootlessness. However, as Rita Felski and Deborah L. Parsons, among others, have pointed out, the modern urban space and its modernist representations are not least permeated with gendered and sexualised tensions and 
conflicts. ${ }^{1}$ While patriarchal patterns of domination prevail and cause difficulties and limitations mostly to women but also to men, modernity implies that new opportunities for a more autonomous life occur-but not seldom at a high cost.

In this essay, I want to discuss the combination of city life and gender performativity in two Norwegian classics, Knut Hamsun's Hunger (1890) and Cora Sandel's Alberta and Freedom (1931) (Sandel [1963] 1984). These are modernist novels depicting lonely human subjects in an urban space, the first one featuring a man in Kristiania (now Oslo) in the 1880s, the second one a woman and her male and female acquaintances in Paris in the 1920s. By gender performativity I understand a way of constructing gender by means of body, appearance, acts and speech, which can be analysed with combined attention to characters, narrators and rhetoric. ${ }^{2} \mathrm{My}$ aim is to interpret and compare the two novels by focusing on their intertwined construction of gender performativity and urban space. As I will show, gender norms of the city life are critical premises for how the subjects manage to negotiate with different options and obstacles through their modern existences.

Hunger and Alberta and Freedom have both inspired a considerable number of readings. Hamsun's novel has been foregrounded as an innovative text of early European modernism and stands out as a classic reference. Main contributions to the discussion of the novel's position as an important breakthrough of modernism are the works by Peter Kirkegaard (1975) and Martin Humpál (1998). They both foreground the novel's protagonist as a lonely, rootless subject in urban life as well as its experimental narrative form. However, while Kirkegaard adopts an ideologically focused approach, Humpál emphasises the novel's narrative techniques.

The novel has, moreover, been repeatedly discussed in the wake of what Hamsun himself saw as a contribution to a new psychological literature. In a manifest-like essay from 1890, "From the Unconscious Life of the Human Mind" (Hamsun 1994b) ["Fra det ubevidste sjæleliv", (Hamsun 1994a)], Hamsun argues in favour of a psychological literature concerned with mental life, as well as with the relationship between creativity and the unconscious. This intentional focus on hidden impulses and drives has inspired psychoanalytical readings, most prominently by Atle Kittang, who in a major study (1984) and other essays underscores the connection between Hamsun's modernity and his psychological writings: "Here, in this astonishing correspondence between the novelist's investigations into the deep conflicts of subjective and inter-subjective existence, and the future revolutions in psychology, lies perhaps the real modernity of Hamsun's early (and even later) works". ${ }^{3}$

Contrary to this psychological approach, other examinations have instead pointed out how the novel focuses on the subject's projections and observations of external phenomena. Within this way of reading, Hunger has been interpreted as an anti-psychological text, for instance by Knut Brynhildsvoll (1998). Its body focus has, furthermore, been underscored by Per Mæleng (1994), who reads the hero's neurosis as bulimia and discloses a textual structure that mirrors the bulimic's rhythm of eating and vomiting. In an extended analysis of its body phenomenology, Hamsun's depiction of the protagonist's gendered and sexualised behaviour has been discussed by Langås (2004).

Cora Sandel's trilogy on Alberta-Alberta and Jacob [Alberte og Jakob, (Sandel 1926)], Alberta and Freedom [Alberte og friheten, (Sandel [1931] 1976)], Alberta Alone [Bare Alberte, (Sandel 1939)]-has attracted several academic readings. Most relevant to mention here are interpretations of the walking and city motif in Alberta and Freedom, which portrays the female protagonist and her life in Paris. In her book on "literary vagabonds" [litterære vaganter], Selboe (2003) explores texts by female authors, who place their heroines strolling around in the metropolis, while being visible and invisible at the

1 The Gender of Modernity (Felski 1995); Streetwalking the Metropolis (Parsons 2000) .

2 The concept of 'gender performativity' is developed in several works by Judith Butler, see Gender Trouble (Butler [1990] 1999), and Bodies that Matter (Butler 1993). Butler's perspective is to theorise about gender in a general sense, while my approach is concerned with the way in which literary texts take part in the cultural construction of gender.

3 Knut Hamsun's Sult (Hamsun 1890, p. 301). 
same time. ${ }^{4}$ Her aim in the Sandel chapter is to show how the city surroundings are integrated motifs in a story of artistic creativity, and also how Alberta's walking is a physical activity that echoes her childhood in a small town in northern Norway. Sensing and perceiving the streets of Paris, night and day, means to create a literary place by means of combined impulses from the memorised past and the experienced present.

In addition, Arne Melberg foregrounds Alberta's walking in his book on traveling and writing (2005). He sees the restless and aimless way of moving around in the city landscape as an essential part of the novel's modernism and observes how its female protagonist, in contrast to her male acquaintances, has no plans and no projects. Curiously, the walking activity is a kind of passivity, he maintains, since it takes part in an existential being-in-the-world which has no declared goal. However, precisely in the tension between dynamism and pause, Melberg finds the poetic imagery that allows Sandel's text to prefigure its important creative writing theme. Paulson (2005) adopts a phenomenological approach to the representation of the city and underscores the image of Paris in Alberta's perception as a magic place.

More concerned with the vulnerable body, Rees (2010) takes the penetration motif as a guiding perspective throughout her analysis of the novel. Literally and metaphorically, the penetration takes place in different ways, she argues, and sorts out its strata in 'architectural penetration', 'artistic penetration', 'sexual penetration', and 'narrative penetration'. The first includes the many scenes where Alberta, but also other women, stay in rooms with a penetrable quality "that relates to the marginalized and transitory status of the people who occupy them". ${ }^{5}$ The second includes several passages where the border between text and image is blurred, predominantly in ekphrasis. These descriptions often tend to function as projections of the gendered conflicts at the novel's discourse level. The third includes sexual relationships, depicted primarily by means of rhetorical substitutions and the gaze, but not least the more explicitly told abortion story of Liesel, Alberta's closest friend. The fourth includes narrative interruptions by memories that subvert epic chronology and permit spatial readings, most notably the novel's most extended flashback, which depicts the death of Alberta's parents.

My comparative reading of the two novels will focus on the gendered identities and relations as they are shaped in a setting of modern urban space and produced by cultural norms. Both novels feature a lonely person without strong social ties, but their different sex causes them to face diverse and, to an extent, opposite challenges. I will show how the two protagonists respond to this situation, and how the modern urban space from this point of view becomes a tempered battleground for gendered controversies.

\section{Masculine Negotiations}

Knut Hamsun's Hunger is generally recognised as the first modernist novel in Norway. In my perspective, it is a text that foregrounds the performativity of a male body and its negotiations with masculine conventions, economic resources and femininity. Hamsun stages a character who experiences an extreme situation of loss, and he constructs a psychological case largely with bodily signs and interior monologue. An important part of this aesthetics, where the point of view is that of the first-person narrator, is the way he interprets the city and its inhabitants by means of physical perceptions, which are governed by his existential state of being hungry. The main character's senses, thoughts and interaction with the surroundings are basically guided by the hungry body, and as a reflection, the outer world leaves its prints on him. The novel's physiological frame is emphasised by the phrase that introduces "Kristiania, that strange city which no one leaves before it has set its marks upon him ..." " (3) [Kristiania, denne forunderlige By, som ingen forlader før han har faaet Mærker af

\footnotetext{
Selboe's study includes texts by Camilla Collett, Sigrid Undset, Cora Sandel, Jean Rhys, Djuna Barnes, and Virginia Woolf. Figurative Space (Rees 2010, p. 89).
} 
den ... (1)], as well as the final description of the man as being "wet with fever and fatigue" (p. 217) ["vaad af Feber og Mathed" (p. 333)]. ${ }^{6}$

A central motif in the novel, which does not have much of a plot, is an encounter with a woman he names Ylajali. Their first meeting takes place when he approaches two women at Palace Hill and describes one of them with words that reveal an erotic tension that increases the I's nervousness and alienation:

"As I walked by, I brushed the sleeve of one of them; I looked up-she had a full, somewhat pale face. Suddenly she blushes and becomes wonderfully beautiful, I don't know why, maybe from a word she'd heard spoken by a passer-by, maybe only because of some silent thought of her own. Or could it be because I had touched her arm? Her high bosom heaves visibly several times, and she presses her hand firmly around the handle of her parasol. What was the matter with her?" (p. 12)

[Idet jeg passered dem, strejfed jeg den enes Ærme, jeg saa op, hun havde et fyldigt, lidt blegt Ansigt. Med ét blusser hun og blir forunderlig skøn, jeg ved ikke hvorfor, maaske af et Ord, hun hører af en forbigaaende, maaske blot af en stille Tanke hos hende selv. Eller skulde det være fordi jeg berørte hendes Arm? Det høje Bryst bølger heftigt nogle Gange, og hun klemmer Haanden haardt om Parasolskaftet. Hvad gik der af hende? (pp. 15-16)]

The woman is represented through selected body parts, which underscores how the man sees her. The "full" face is, in the context of hunger, a sign of wealth and sufficient nourishment, and paleness is, in the 19th century, a colour of fashion. Her "high bosom" and the word "blushes" more than suggest erotic longing and willingness. In addition, her hand, that presses "firmly around the handle of her parasol", is a detail that, in this context, has sexual connotations. The passage discloses a connection between the way he looks at her and the interpretations he plays with, namely that he is the one who makes the lady vibrate. But to the reader, it is his own desire that is exposed in this way.

However, the encounter takes a surprising turn: "I'm seized by a strange desire to frighten this lady, to follow her and hurt her in some way. I overtake once more and walk past her, then abruptly turn around and meet her face to face to observe her" (pp. 12-13) [ ... jeg føler mig greben af en sælsom Lyst til at gøre denne Dame bange, følge efter hende og fortrædige hende paa en eller anden Maade (p. 16)]. He tells the lady several times that she has lost her book, although she does not have one, and annoys her by coughing and making the "stupidest faces" (p. 13) [dummeste Grimaser (p. 16)] behind her back. He loses control of himself and cannot identify with the one who behaves like this. Since the point of view is that of the male character, he has no access to the lady's mind, and instead interprets her thoughts based on bodily signs, primarily her eyes. In them, he reads confusion, fear, curiousness, but also an erotic interest, and he shadows the two women until they arrive at their home at St. Olav's Place. She watches him through the window, and leaving the scene, he continually senses her pursuing eyes in his neck, and a cold shiver runs down his back.

The sexual motif in Hunger is characterised by the same humiliating deficiency as everything else in the man's life, and like the lack of food and money, the lack of sex is exposed in ironic and partly grotesque situations. The erotic scenes in the novel serve throughout as a reminder of his exclusion from this part of life also, and at the same time, they underscore the novel's bodily aesthetics. $\mathrm{He}$ may take part in sexual activities but is also regularly an outsider where he compulsorily obtains a voyeuristic position. The picture of gender relations and sexual forms that is drawn in the novel shows a world that has very little to do with official bourgeois practices. Familial frames around sexuality are abandoned, and instead, sexual life unfolds outside of the homes or as a grotesque inversion of conventional notions.

6 I quote from Knut Hamsun: Hunger (Hamsun 2016), and its first edition, Sult (Hamsun 1890). 
The reader gets access to some of the I-person's erotic fantasies, which seem to be shaped by romantic idealisations of women. The contrast to his real experiences is stark and points to the ironic pattern into which even the sexual motif is inscribed. His first fantasy of a woman occurs in the conversation with an old, blind man. It presents itself as an invented story, but the woman is called Ylajali and is the daughter of a man called Happolati, who lives at 2 St. Olav's Place. Happolati is a cabinet minister in Persia and his daughter a fairy princess who lies on a bed of yellow roses and owns three hundred women slaves. Very conscious of his own invention of "desperate lies" (p. 26) [desperate Løgne (p. 37)], the I-person describes the woman like this: "Eyes like raw silk, arms of amber! A single glance from her was as seductive as a kiss, and when she called me, her voice went straight to my heart, like a jet of wine" (pp. 26-27) [Øjne som Raasilke, Arme af Rav! Bare et enkelt Blik af hende var forførende som et Kys, og naar hun kaldte paa mig, jog hendes Stemme mig som en Straale af Vin lige ind i min Sjæls Fosfor (p. 38)]. The contrast between this ideal of a woman and an ordinary version of the second sex is articulated as a critique of the old man's reluctance to let himself be persuaded by the story. However at the same time, it is obvious that the I-person himself does not believe in his own account.

The real Ylajali does in fact come to him, and the pattern is repeated. Three evenings he has observed her outside the gate of his lodgings, and even though she is very well veiled, her attributes disclose her identity. She is wearing black, has a veil over her face and bosom and has a parasol with an ebony ring on the handle. His reaction is tense and typically depicted as a physical response: "My nervous brain shot out its feelers" (p. 113) [Min nervøse Hjærne skød Følehorn ud (p. 167)]. When he does not dare to approach her or offer to accompany her back home, it is because he intuitively thinks something will be required, a glass of wine or a ride. In addition, he is hungry, and although he had food just one day ago, he is not as capable of being hungry as before. The woman's expectations, in other words, force him to direct the claims of desire as well into an economic structure. When he uses the lack of money and his hunger as an excuse to keep the woman at a distance, it may seem as if there are other, less explicit, motifs behind his hesitancy. Hence, his sexuality is intimately tied to economy and power, but the relation is complex and far from transparent.

This point is further developed when the I-person, after an unsuccessful excursion around the city to find food and money, ends up at Karl Johan Street around eleven pm and encounters the sex market in full bloom: "Rustling skirts, a few bursts of sensual laughter, heaving breasts, excited, panting breaths; far down, by the Grand Hotel, a voice calling, 'Emma!'. The entire street was a swamp, with hot vapours rising from it" (p. 115) [Raslende Pigeskørter, en og anden kort, sandselig Latter, bølgende Bryster, heftige, pæsende Aandedrag; langt nede ved Grand en Stemme, som raaber: 'Emma!' Hele Gaden var en Sump, hvorfra hede Dunster steg op (p. 171)]. This impressionistic description of the sex industry is inscribed with feminine and animal characteristics, but our man does not have the means to participate:

"I instinctively search my pockets for two kroner. The passion quivering in every movement of the passers-by, the dim light of the street lamps, the tranquil, pregnant night-it was all beginning to affect me: this air filled with whispers, embraces, trembling confessions, half-spoken words, little squeals. Some cats are making love amid loud shrieks in Blomquist's entranceway. And I didn't have two kroner. It was a torment, a misery like no other, to be so impoverished. What humiliation, what disgrace!" (p. 115).

[Jeg forfarer uvilkaarlig mine Lommer efter to Kroner. Den Lidenskab, der dirrer i hver af de Forbigaaendes Bevægelser, selve Gaslygternes dunkle Lys, den stille, svangre Nat, altsammen har begyndt at angribe mig, denne Luft, der er fyldt af Hvisken, Omfavnelser, skælvende Tilstaaelser, halvt udtalte Ord, smaa Hvin; endel Katte elsker med høje Skrig inde i Blomqvists Port. Og jeg havde ikke to Kroner. Det var en Jammer, en Elendighed uden Lige at være saa udarmet! Hvilken Ydmygelse, hvilken Vanære! (p. 171).] 
He is denied the pleasure because he is poor and cannot compete with the bankers and grocers, onto whom he instead pours out his contempt. Arrogance replaces negotiations, and this attitude also influences the conversation with one of the women who catches his attention with her gaze. The conversation with her discloses the ambiguous attitude of both towards the game in which they are taking part, and whose rules they both quickly break. He plays the patron, aware of the fact that he does not have a dime to invest in the service offered but is taken by surprise when she wants to come with him for free. Humiliated by this generous proposal from a poor hooker, he says no thanks. While he has earlier regretted his lack of money to buy a sexual service, he now finds an excuse to escape. While he earlier let himself be overwhelmed by the passions of the erotic scene on the city street, his desires have now disappeared. To rescue himself from this embarrassing situation with a small amount of honour, he presents himself as a clergyman and recommends that the girl walk away and sin no more. We are here witnessing a play in three acts in which our hero approaches the sex market firstly as a customer, but with a clear conscience of not being serious because of his lack of money, secondly as fatherly caretaker for the poor girl who must sell her body to anyone, and thirdly as a Christian pastor with moralising accusations against a sinner in the flesh.

In all the roles, he plays with existing conventions but does not fit into any of them. He is an outsider in relation to existing role models in the culture and is instead ready to exploit them to his own favour and satisfaction. Moreover, these roles are infected by money and the power of market mechanisms. The law of the market decides who has and who does not have the necessary resources to be active agents, and on these terms, Hamsun's man is unable to compete. As soon as this law is redefined and other criteria rule, he can play the game, but is then suddenly uninterested in the whole business. Both Ylajali and the unknown young prostitute seem to appreciate qualities in the I-person other than his economy and status, but it is exactly this material aspect that he himself foregrounds in his relationship with them. It can, in other words, be tempting to interpret the I-person's relations to women and sex psychologically, as fear, reluctance, impotence, etc., but his own understanding emphasises that his problems are due to the lack of material resources.

The next day he observes the black veiled lady again by the gas lamp outside his gate, and this time he initiates a conversation, probably more self-confident because he has some money in his pocket. She agrees to letting him bring her home, and during this walk, occupies his senses in a way that hardly describes her but instead the qualities that stimulate his desire:

"We started off; she walked on my right-hand side. A peculiar, lovely feeling took hold on me. The consciousness of being in the presence of a young girl. I didn't take my eyes off her through our walk. The perfume in her hair, the warmth radiating from her body, this fragrance of woman that surrounded her, that sweet breath every time she turned her face towards me-all this streamed in upon me, penetrating irresistibly all my senses. I could just barely make out a full, somewhat pale face behind her veil and a high bosom that strained against her coat. The thought of all this hidden loveliness, whose presence I sensed under her coat and behind her veil, was bewildering to me and made me idiotically happy without any sensible reason. I couldn't hold back any longer and touched her with my hand, fingering her shoulder and smiling daftly. I could hear my heart pounding" (p. 128).

[Vi satte os i Bevægelse; hun gik paa min højre Side. En ejendommelig, skøn Følelse greb mig, Bevidstheden om at være i en ung Piges Nærhed. Jeg gik og saa paa hende hele Vejen. Parfumen i hendes Haar, Varmen, der stod ud fra hendes Legeme, denne Duft af Kvinde, der fulgte hende, det søde Aandedrag hver Gang, hun vendte Ansigtet mod mig,- -altsammen strømmed ind paa mig, trængte mig uregerligt ind i alle mine Sandser. Jeg kunde saavidt skimte et fyldigt, lidt blegt Ansigt bag Sløret og et højt Bryst, der strutted ud mod Kaaben. Tanken paa al denne skjulte Herlighed, som jeg aned var tilstede indenfor Kaaben og Sløret, forvirred mig, gjorde mig idiotisk lykkelig, uden nogen rimelig Grund; jeg holdt det ikke længer ud, jeg berørte hende med min Haand, fingred ved hendes Skulder og smilte fjollet. Jeg hørte mit Hjærte slaa (pp. 192-93).] 
The erotic tension between Ylajali and the I-person started with a dynamic of gazes in their first encounter and continues here with a conversation that typically reveals him as unpredictable and emotionally unbalanced. However, it is also more successful since the meeting ends with a kiss. In this scene, the mechanisms of power are intimately tied to the choreography of undressing that often dramatises an erotic game. She is wearing a black veil that covers her face and bosom, while he is eager to discover what it hides. He asks her twice to take it off, while she uses it as a means of negotiation, firstly to tickle his senses, and secondly to accept his plea:

"Suddenly she made a resolute movement and pulled her veil up over her forehead. We stood looking at each other for a second. 'Ylajali!' I said. She rose on her toes, flung her arms around my neck and kissed me right on the lips. I could feel her bosom heaving, hear her rapid breath" (p. 135).

[Pludselig gjorde hun en resolut Bevægelse og trak Sløret op i Panden; vi stod og saa paa hinanden et Sekund. Ylajali! sagde jeg. Hun hæved sig op, slog Armene om min Hals og kyssed mig midt paa Munden. En eneste Gang, hurtigt, forvirrende hurtigt, midt paa Munden. Jeg følte, hvor hendes Bryst bølged, hun pusted voldsomt (pp. 202-3)].

The gaze, the voice and the bodily touch represent in condensed form the stepwise scenography of perception that characterises their relationship.

At the same time as the contest of Ylajali's body goes on and is played out as a fight about the veil, the I-person's body appears-in an interesting inversion of the conventional gender roles in this ritual-as increasingly naked. Instead of the female striptease dancer who throws away her clothes one by one, the male character's sparse and untidy wardrobe is disclosed. It starts, not very "dangerously", with his observation of a passing man who carries a pair of shoes under his arm, as if he wants to spare them from being worn out. Then Ylajali asks him if he is cold without an overcoat, to which he answers "No, not at all" (p. 130) ["aldeles ikke" (p. 195)], since a confirmation would reveal his sorry condition. His shabby clothing signifies his economic situation, which is intricately embedded in a complex relation to the erotic negotiations that go on between the two. In his thoughts, the bad wear causes trouble in his relationship with the woman, and he seemingly does not understand why she wants to have anything to do with him at all. This theory of his explains why he offends her again, as if he will push her away: "You shouldn't really be walking here with me, miss; I compromise you in the eyes of everybody by my clothes alone" (p. 132) ['De burde i Grunden ikke gaa sammen med mig, Frøken; jeg prostituerer Dem midt for alle Folks Øjne bare ved min Dragt' (p. 197)]. Again, according to the reversed gender conventions, she shakes the humiliation away and sticks with the man.

In this scene with Ylajali, the erotic issue is complicated by the I-person's tendency to ascribe great significative dominance to clothing, both in his thoughts and in his conversation with her. The clothes obviously signify his economic shortage, but they also belong to the cultural context that attributes certain values of appearance in the interaction between the genders. Hat, overcoat and waistcoat are clothes without which the man clearly feels naked, and the lack of these items makes him subordinate and weak in his own eyes. His irrational and offensive statements are connected to this gender norm in the text, and when the rendezvous all in all turns out rather successful, it is due to her. She, on her part, lets herself be represented by a veil that she uses as an entrance to the body that he desires and to which she regulates access.

The epiphany of the erotic storyline is the scene where he is invited into Ylajali's apartment and sexual pleasure is within reach. In this case also, body and clothing mark the profound asymmetry between them and underscore the male's weakened masculinity in the erotic game: "Oh, that wretched suit I was wearing!" (p. 158) ['Aa, det elendige Antræk, jeg havde paa!' (p. 241)]. His desire is expressed in bodily reactions: "I sat looking at her with rapt attention. My heart was thumping, the blood coursing warmly through my veins" (p. 160) [Jeg sad fortabt og saa paa hende. Mit Hjærte slog højt, Blodet spændte mig varmt gennem Aarene (pp. 243-44)]. With a sore foot, however, he is physically handicapped and unable to play the cat-and-mouse game around the table to which she 
invites him. His attitude is deeply ambivalent the whole time and is expressed in a recurrent double communication. He has shaved his beard but is stumbling in his chase after her; he manoeuvres her down on the sofa and gets to see her breast but has a lot of loose hair on his shoulders. He confesses his emotions and verbalises his desire but also tells her about his poverty and his humiliations. The scene closes with her embracing him and offering a love that he is unable to receive. "She offered me her mouth but I couldn't believe her, it was bound to be a sacrifice on her part, a means of getting it over with" (p. 170). [Hun rakte sin Mund frem; jeg kunde ikke tro hende, det var ganske bestemt et Offer, hun bragte, et Middel til at faa en Ende paa det (p. 261)]. He rushes to the door and walks out backwards-a final sign of his ambivalence, disgrace and fiasco as a seducer.

As a grotesque replica of this unsuccessful event, the man is invited by his landlord in Vaterland to witness an act of intercourse between the landlady and a sailor. ${ }^{7}$ While the two men are peeping through the hole, the husband is almost entirely occupied with the old man on the couch beside, who is involuntarily forced to observe the sexual act: "Just look!' he said, laughing with quiet, excited laughter. 'Take a peep! Hee-hee! There they lie. Look at the old man! Can you see the old man?'” (p. 202) ['Se her!' sagde han og lo med en stille, hidsig Latter. 'Kig ind! Hi-hi! Der ligger de! Se paa Gammeln! Kan De se Gammeln?' (p. 308)]. He repeats his utterance after the I-person has peeped through the hole: "'Did you see the old man?' he whispered. 'Oh Lord, did you see the old man?'” (p. 202) ['Saa De Gammeln?' hvisked han. 'Aa, Gud, saa De Gammeln?' (p. 309)]. With this explicit reference to the lame old man's voyeuristic position, the two of them, the I-person and the old man, reflect each other. Earlier, the old man's situation has been like the I-person's since they have both been bullied by family members. The children, two girls, have been jumping up and down on the old man's body, sticking straws into his ears and stabbing at his eyes and nostrils without him being able to defend himself, except to spit on them.

This scene reflects the I-person's total humiliation as a sexually active man. ${ }^{8}$ He has been thrown out of his bed and his room, while the sailor has moved in, and is left with an outsider position. This status is prefigured in the scene in Ylajali's home, as well as in a situation on the street where he sees her for the last time. Here, she is synecdochically named a "red dress" (p. 189) [en rød Kjole (pp. 288-89)] and even a "blood-red dress" (p. 191) [en blodrød Kjole (p. 291)] several times and is accompanied by the "Duke" ['Hertugen' (p. 290)]. Our man's response to this defeat is expressed as selective perceptions and judgements of the quality of this colour, and the fate of being knocked out by this other man turns into a verdict of Ylajali's appearance: "I no longer cared for her, not at all; she wasn't the least attractive any more, she had lost her good looks-bloody hell, how she had faded!" (p. 191) [Jeg brød mig ikke længer om hende, aldeles ikke; hun var ikke det allerringeste vakker mer, hun havde tabt sig, fy Fan, hvor hun var falmet! (p. 291)]. In contrast to Ylajali's red, the landlady's body is white, "her legs gleamed white against the dark quilt" (p. 202) [hendes Ben skinned hvide mod den mørke Dyne (pp. 308-9)]. With the added description that she also always appears as pregnant, it is clear that the women in these scenes, where the I-person's sexuality is a theme, are represented as one body part, one attire or one colour. This synecdochic rhetoric can be read as a sign of the I-person's own exalted condition and is an expressionist way of writing that condenses the power of emotion in one single sign.

The connection between sexuality and money in the novel is underscored to the bitter end and it transmits the gender relations from the sphere of intimacy on to the market. When the I-person receives ten crowns from an unknown donor, he throws the crumpled note in the face of his landlady.

7 This scene has been left out in George Egerton's translation, which is accessible online on Project Gutenberg (released 2005).

8 In Per Stounbjerg's reading, this scene shows how female sexuality works as a symbol of the border-transgressing modernity: "The scene is presented for the male gaze, and it is written and staged from a male's perspective, Hamsun's. The female culture is a product of the male gaze. If we look behind the key hole, behind the city's shiny façade, the terrible appears" [Scenen præsenteres for mænds blikke, og den er skrevet, iscenesat ud fra en mands optic, Hamsuns. Den kvindagtige kultur er produkt af et mandligt blik. Kigger man ind gennem nøglehullet, ind bag byens skinnende facade, begynder det skrækkelige] ((Stounbjerg [1985] 1990) “Modernitetens køn”, p. 84, my translation). 
However, when he realises that it comes from Ylajali, he grows "[s]ick with pain and shame" (p. 208) [syg af Smærte og Skam (p. 318)]. Instead of digging her into the mud, as he earlier wished to do, he now wishes that he himself would sink: "I was sinking, sinking everywhere I turned, sinking to my knees, to my middle, going down in infamy never to come up again, never!" (p. 208) [ ... jeg sank, sank paa alle Kanter, hvor jeg vendte mig hen, sank tilknæs, sank til livs, dukket mig under i Vanære og kom aldrig op igen, aldrig! (p. 318)]. The erotic pleasure and humiliation are fundamentally tied up with economy, and success or fiasco on the sex market is consequently related to material resources. Our male character does not miss access to women and sex. On the contrary, the portrayed women, both the prostitute and Ylajali, are astonishingly willing despite his continuous performance as a shameful, poor, and unsympathetic person.

\section{Feminine Negotiations}

Alberta and Freedom is the second volume of a trilogy. ${ }^{9}$ Told in a third person narrative and consistently from the point of view of the main character, it features Alberta, who tries to make a living in Paris in the 1920s and is at the centre of a vivid character gallery not least populated by other women. They have common intimate experiences and similar problems but are also foreign and distanced from each other. Encounters take place in outdoor places, in cafés, at market places, on streets, while glimpses of indoor life are rare but significant.

The opening scene describes Alberta as a nude model at work for the dilettante painter Mr. Digby. She lets her clothes fall in front of him and does not first and foremost feel embarrassed but rather fears that something could come too close and hurt her. She enters the podium with a dizzy feeling and compares it to throwing herself into the sea, but then pulls herself together and concentrates on standing in the right position. The scene is an exemplary introduction to Alberta's life, which is a permanent condition of being exposed to other people's gaze and judgements, to loneliness and poverty, and to unfulfilled dreams. Her strong sense of being captured in an inert existence without outlined plans or a drive for action is a main component of this state of living. Significantly, the initial scene also introduces artisan life and its gender aspects as the context of the narrative, as well as the economic motivation behind the engagement as a nude model. The job means necessary income and is free of risk but must nevertheless be hidden.

This opening sequence puts the fragile female body in the foreground of the story and constitutes an interpretation of a life. The naked body that "stands", exposed to other people's gaze and objectified in the process of artistic representation, functions both as a realistic description and as a metaphor for fear and vulnerability. ${ }^{10}$ Living on the edge of decency, on a precarious minimum for existence, and barricading herself behind solid mental walls of defence, are recurring themes in Alberta's self-understanding. The undressing takes place in an area of the city far from the people she knows and frequents daily, but even so, she is not completely safe. Sometimes, elderly and "exceedingly respectable" (p. 7) [særdeles respectable (p. 9)] men occur, present themselves as "'admirers of Mr. Digby's art'" (p. 7) ['beundrere av mr. Digbys kunst' (p. 9)] and have no business there other than to look. In a subtle and ironic manner, the text communicates the current norm, which stipulates that the respectable position is to look and not be looked at, and that this respectable side is masculine and the opposite one feminine.

The border between a model and a prostitute could be blurred because many women were both, or they were the artist's model as well as his mistress. ${ }^{11}$ The outworn question "Tu viens?" is a recurrent

9 Sandel, Alberta and Jacob (Sandel 1926), Alberta and Freedom (Sandel [1931] 1976), and Alberta Alone (Sandel 1939). I quote from (Sandel [1931] 1976).

10 The penetration metaphor that Ellen Rees uses this scene to introduce is, in my opinion, well underpinned in her reading: "It seems to me that this fear might best be expressed as a fear of penetration, understood on various metaphorical and literal levels, and that this is a recurring motif and as such a major element of the text" (Rees 2010) Figurative Space, p. 75.

11 Streetwalking the Metropolis (Parsons 2000). 
invitation that echoes around Alberta when she walks in the streets, reminding her indiscreetly of her risky position in the gendered sign system of the city. Ironically, both Alberta and her friend Liesel end up working as nude models for their artist lovers, Sivert and Eliel, but for free. The model job is only a way of earning money, but the situation changes as soon as the artist and the lover are the same person. Liesel's destiny prefigures Alberta's, and an important component in this process is the offered or compulsory role at hand, namely as a mix of sexual and artistic objects. This process, which generally means that the woman must give up her own artistic ambitions, is meticulously described in Sandel's narrative and represents an important dimension of its gender critical perspective.

Liesel is a painter, but she experiences what we are told to understand as a typical female career. She sits model for the Swedish sculptor Eliel, makes him coffee, sews the buttons on his shirt. In Sandel's subtle rhetoric, it becomes clear that one thing leads to another: "I pose for the head', said Liesel. 'For the head, Albertchen'. 'I know - and for a hand, and for a shoulder. If it goes on like this ... '"' (p. 16) ['Jeg sitter for hodet, sier Liesel: For hodet, Albertchen-Ja—og for en hånd, for en skulder. Skal det fortsette slik__ ' (p. 15)]. And that is exactly how it goes on, because one day, when Eliel's model does not show up, she takes off her clothes, and ultimately, she is not only a model but a mistress, implying that her own painting ambitions must be set aside.

Later in the novel, Alberta stays in Eliel's atelier while he and Liesel visit the countryside. Now she is a guest and an observer in the artist's room, not a model, and she wonders about Liesel's situation in this interior where the plaster figures vainly try to "lift their heavy limbs towards each other" (p. 90) [løfte de tunge lemmene sine mot hverandre (p. 74)]. The sculptures throw a confirming reflection back on the analysis that Alberta makes about her friends and their relationship to each other, and the sculptor's atelier becomes a sinister imprint of a disturbing relationship. Eliel's portrait of Liesel obtains a central space that is both material and metaphoric in this landscape of figures. On the one hand, it is his first work of marble, an expensive material. On the other, there is a "brass instrument of torture" (p. 90) [torturredskap av messing (p. 75)] penetrating it, and Alberta cannot but think of Liesel when she notices how the brass "had bored a sharp hook right into one nipple, which was almost loosened from the block, and another hook into the navel" (p. 90) [har boret en hvass tagg rett inn i en brystvorte, som så vidt er frigjort fra blokken, en annen tagg i en navles runding (p. 75)]. This metaphoric connection between the unfinished marble sculpture with brass tags and Liesel's body points mercilessly at her subjected position in the relationship with the artist and forecasts her later devastating abortion. ${ }^{12}$

The women in Sandel's novel are artists, but precisely also women. In the depiction of the artist women's lives in the metropolis, the author emphasises how their art is inextricably connected with their gender. That is, most of the women are not only autonomous artists, but also models and mistresses to male artists, and thus, objects in these male artists' aesthetic representations. The artist women's lives are characterised by a daily fight for survival on a minimum income, and their sense of happiness or unhappiness is decided more by their intimate relationships than by their art.

The female minor figures make up an international collage around the main character's life. Early in the novel, these women, both French and foreign, are described by some common traits. Alberta conceives them as a "series of elderly women perpetually trudging round Montparnasse" (p. 19) [en rekke halvgamle kvinner, som trasker om på Montparnasse (p. 18)]. They have wrinkles and grey hair, and they "dragged themselves round with large bags full of brushes over one arm, their camp stool and easel under it, a wet canvas in each hand and their skirts trailing behind them" (p. 19) [drasser rundt med store penselposer på armen, feltstol og staffeli under den, et vått lerret på blindramme $\mathrm{i}$ hver hånd og skjørtene slepende efter seg (p. 18)]. They paint in a similar way and frighten Alberta by the thought of having to walk around in the city, year in, year out, as an old, ugly dilettante. The

12 Liesel's abortion is a main theme in the novel, but I will not go further into that here. Cf. (Langås 2014). 
individual characters that appear among them, as impressionistic spots on a faint background, are Wolochinska, Potter, Alphonsine, Marushka, and Liesel.

The lonely Polish Wolochinska lives in the same hotel as Alberta, in one of the better rooms towards the street. On two occasions we get an impression of her circumstances. On the first occasion, Wolochinska asks Alberta into her room for a cigarette, invites her out for dinner, and asks for an opinion on a painting, a cubist study. Behind the pale, bright, somewhat stiff woman in the door opening, Alberta observes a room with a controlled, pink light, decorated with things of which she cannot even afford to think. Perplexed, Alberta attempts to say something about the picture, but it is as if the painting and the woman are mixed in one and the same perception: "The daylight fell palely on the thick layers of color and on her own angular features under the smooth, close-cropped, very fair hair" (p. 24) [Dagskjæret slår blakt mot billedets tykke lag av farve og mot hennes egne, kantete trekk under glatt, kortklipt, meget lyst hår (p. 22)]. Despite her own loneliness, Alberta says no thanks to entering and hurries away. Later, it becomes clear that her reluctance is due to Wolochinska's being a lesbian.

The second time, the invitation becomes more explicit and erotically distinct. It is summer, and, like many other Parisians, Wolochinska is going to the countryside. When Alberta passes by, Wolochinska suddenly appears in the doorway wearing a kimono and invites her for a cold drink. Her friendliness is a gesture that Alberta neither understands nor returns, and she is afflicted by a bad conscience and an instinctive uneasiness towards this woman whom she repeatedly tries to avoid. This time, the invitation is more wide-ranging, since she asks her to come with her to the countryside, but Alberta feels uncomfortable in the company of this woman who manages to give her a kiss on the mouth. Confused and self-critical, Alberta withdraws to her room.

Potter is the American woman who first and foremost represents the old women that are trudging around the city with their easels. Among the friends that are gathered in Marushka's room, she appears as a still life with eyes that are "screwed up into slits in her tired, ageing face" (p. 46) [knepet sammen til streker i det trette, aldrende ansiktet (p. 40)]. Potter utters brutal and disgusting things about men's relationships with women, things that, after all, appear in proportion. Her bitter words are effective, probably because they are uttered against the background of bitter experiences. Alberta freezes when she listens to Potter even though the American lady is friendly enough. "Men are like hungry dogs, I always told you- - - ", she says in her mother tongue, and continues in French: "It is a woman's misfortune to think with her heart. Man thinks with something a little lower down" (p. 48) [Det er kvinnens ulykke at hun tenker med hjertet. Mannen, han tenker med noe som sitter lavere-(p. 41)]. This statement causes disturbance around the table but, seen together with Liesel's destiny, it achieves an ominous truth value.

The French model Alphonsine is the stable and motherly person who always supports Alberta and helps her get the job with Mr. Digby. While Potter recommends that Alberta work and not let the men obstruct her, Alphonsine advises her to find herself a man, "Il vous manque une affection mademoiselle- - - " (p. 72). However, Alphonsine is also critical, and she warns Alberta against Sivert, in the same way as she warns Liesel against Eliel. All in all, she is, with her advice woman to woman, quite ambiguous, since she prophesies on the one hand a life of happiness if she finds a man, and on the other hand, teaches her that men are trustless and egocentric. Alphonsine's look is characteristically described as if it were a painting:

"Above her short, broad face, in which the skin and muscles were stretched spare and taut across the cheek-bones, red hair jutted out in a thick wave and was gathered up diagonally on top of her head in an oblong roll. A painted mouth and two large irises, green as a cat's, stood out in violent contrast to her powder-white skin. Beneath her eyes it looked as if brownish blue shadow was eating in deep. It gave her a ravaged, battered, almost defaced look. She smiled with large, strong teeth" (p. 51).

[Over det korte, brede ansiktet, hvor hud og muskler sitter knapt og spent over kinnbenene, ligger rødt hår frem i en tykk bølge og samles oppe på hodet i en avlang rull på tvers. En 
malt munn og to store, kattegrønne iris står brutalt mot den pudderbleke huden. Under øynene er det som om brunblå skygge åt seg i dybden. Det gir henne noe herjet og medtatt, nesten beskadiget. Hun smiler med store, sterke tenner (p. 44)].

Marushka is a Russian artist who "glided from one affair to another incredibly easily" (p. 72) [ufattelig lett og sorgløst glir fra det ene til det andre (p. 60)]. She is an expert in both art and men, and her advice to Alberta deals with both. She has also observed the qualities of Liesel's work and is critical to her studies at Colarossi, which in Marushka's eyes is a dilettante art school. In Sandel's portrait, Marushka is a woman who utilises the advantages of her gender, not least as they are depicted in the colourful scene where Alberta, in an emergency, comes to ask her for a small loan. The scene delicately suggests that Marushka is not only an artist, but also does a little business on the side-with her body.

Marushka has installed herself in an erotic scenography because she expects a man, and it becomes clear to Alberta that she not only arrives at an inconvenient moment but also that her Russian friend-by aesthetic means-knows how to make herself attractive. Inspired by art motifs, she has placed herself in a setting with red lights from a paraffin stove, and above the divan there is a single gas jet with a rose-coloured silk shade over it. "Under it Marushka was enthroned with her legs drawn up beneath her, supported by brightly coloured cushions on all sides like the inhabitant of a harem" (p. 187) [Under den troner Marusjka med bena trukket oppunder seg, støttet av farveprektige puter på alle kanter som en haremsdame (p. 153)]. She is wearing a black kimono with gold embroidery and lets her small pink toes appear under the fabric. From the table beside her, smoke from an incense lamp curls up in arabesque forms; a cigarette rests in Marushka's hand. "Between the kimono and her short hair her face, neck and breast had something satisfied and creamy-white about it, a strange, thick fullness, here and there toning into the rose-coloured light from the lampshade" (pp. 187-88) [Mellom kimonoen og det kortklipte håret har ansikt, hals og bryst noe mettet og fløtehvitt, en eiendommelig, tett fylde, hist og her tonende over i rosa fra skjermen (p. 154)]. Doubtless, Sandel has here portrayed a woman in an ekphrastic way, using an art motif as inspiration. ${ }^{13}$

The German Liesel is not only a sad character because of her love story and abortion experience, she is also a promising artist. Liesel is Sandel's main example of a woman who negotiates through existence and tries to make her artist life and her human life go together. Liesel is talented, disciplined and works hard; she goes to the Academy Colarossi, she goes to the Pont Neuf and the Luxembourg Garden with her easel and palette, and she draws croquis, quick and sketchy drawings of a live model. However, Liesel tends to overwork her paintings thus destroying them, and when Alberta sees a study from Pont Neuf with the back turned out, she takes it as a bad sign: "Traces of yellow ochre along the edge of the canvas frame and on the skirt of Liesel's dress emphasized the connection between them" (p. 13) [Spor av guloker langs blindrammens kant og på Liesels kjoleskjørt markerer tydelig sammenhengen mellom den og henne-- - (p. 13)]. Considering Liesel's story, this observation is significant. The destroyed painting that must be hidden, the spots on her dress, and the suggested connection between art and gender, can be read as signs, not only of the difficult combination of woman and artist, but also of the problematic pregnancy that must be terminated. In this observation of the physical relation between the painting and Liesel's body, Sandel manages to hint at the future complications, thereby making Liesel's destructive tendencies a predestination of her tragic abortion.

However, it is not Sandel's intention to make this victim position a final statement of the female artist's abilities. When Liesel's unfinished or overworked paintings are mentioned, the contextual circumstances always explain what happens. And when she completes a work, it seems to be of high quality. One of her paintings is accepted at the autumn exhibition, and Marushka describes how many

13 The kimono is several times associated with women in erotic situations. Taking Marushka as an example, as she installs herself among silk cushions in pink lightning, expecting a friend or a customer, the "woman in kimono" becomes an unequivocal image of bodily and sexual accessibility. Alberta is obviously aware of these aspects of the kimono, but at the same time, she enjoys wearing it because it gives the air access to her senses. The "woman in kimono" motif was a favorite in French contemporary art at the time. 
of her artist friends have given the work a very positive critique; only Sivert thinks it must have been a coincident and cannot understand why Liesel's picture has a prominent display while Eliel's statue has been pushed into a corner. In a suggestive manner, Sandel reveals the gendered prejudices that female artists must fight; her narrative also seems to imply that the private sphere is a larger obstacle than the public one for a female talent to develop.

In her Paris novel, Sandel depicts women who have broken with their bourgeois background and try to live autonomous and independent lives. She describes the "New Woman" 14 with an intention to work herself through, regardless of basic problems of both an economic and ideological kind. Sandel introduces motifs like pregnancy and abortion, prostitution and nude modelling, as well as a general portrayal of women's precarious conditions in the urban space. She lets her text be influenced by references to visual arts and aesthetic norms, but her female protagonists must renounce their own artistic ambitions as soon as they get erotically involved with men. Alberta's life resembles Liesel's, but she decides to keep her baby when she gets pregnant. Slowly, she starts writing small pieces that she secretly collects in her suitcase, hoping that they may someday be the start of an authorship.

\section{Urban Observers and Gender Norms}

Charles Baudelaire and Walter Benjamin famously introduced the motif of the observing artist of urban life and coined the concept of the flâneur, both inferring that this modern subject was male (Baudelaire [1863] 1964; Benjamin 2006) . Some gender scholars have supported this view and, like Griselda Pollock, maintained that "there is no female equivalent of the quintessential masculine figure, the flâneur: there is not and could not be a female flâneuse" ${ }^{15}$ Main arguments were the social conditions, which were different for men and women, and women's lack of access to parts of public life. Others have instead found female representatives of the flâneur and, like Deborah L. Parsons, emphasised the term's not only socio-historical meaning but also its significance as a metaphor for the perspective of the modern urban subject and its gender ambiguities. ${ }^{16}$ Without inserting our two novels directly into this flânerie discussion - they do not quite correspond to the idea of a city stroller and lover of life unconfined of substantial problems-I will use the idea of an urban observer, male or female, confronted with gendered norms in a modern metropolis, as a guideline for a concluding comparison.

In this sense, and to underscore the artistic tradition, I will follow Tone Selboe's view in her study of female city strollers, where she distinguishes between the flâneur and these women:

"I will call them literary vagabonds, the women who tell (about) the city, and this concept includes both the authors themselves and their fictive persons. They let themselves be carried away by the wings of their feet and the desire of their eyes, they look, paint and write, they sit and walk, they stroll around, they do nothing, they protect themselves from invading gazes and close steps; they are travellers in the world of the street-whether they are abroad or at home-but in their restless drive for an identity and a place of their own, they do not possess much of the self-conscious pose of the classic flâneur. They are all city strollers and can thus be said to share some of the traits of the flâneur, but they only exceptionally approach the metropolis with a conscious act of situating or positioning themselves in order to turn impressions into expressions. It is rather the random event, the map of memory or the unmotivated longing that impels the walking." 17

\footnotetext{
14 The "New Woman" is a concept that emerged in the late 19th century to refer to women who sought independence and became feminist models of a radical change. Cf. Witt-Brattström (ed.), The New Woman (Witt-Brattström 2004).

15 Vision and Difference (Pollock 1988, p. 71).

16 Streetwalking (Parsons 2000, p. 4).

17 Litterære vaganter (Selboe 2003, p. 10, my translation).
} 
[Jeg vil kalle dem litterære vaganter, kvinnene som forteller (om) byen, og i den betegnelsen inngår både forfatterne selv og deres fiktive personer. De lar seg rive med av føttenes vinger og øyets lyst, de betrakter, maler og skriver, de sitter og de går; de streifer om, de driver dank, de beskytter seg mot invaderende blikk og nærgående skritt; de er på reise i gatens verden—enten de er i utlandet eller hjemlandet—men i sin rastløse drift etter egen identitet og eget sted eier de lite av den klassiske flanørens selvbevisste positur. De er alle byvandrere og kan derfor sies å bære noe av flanørens merke i pannen, men de inntar bare unntaksvis en bevisst situering eller posisjonering i forhold til storbyen i den hensikt å forme inntrykk til uttrykk. Det er snarere tilfellet, erindringskartet eller den umotiverte lengselen som er vandringens drivkraft.]

Hamsun's Hunger constructs an urban space from the point of view of a man who has no described background and struggles to make a living as an author. His activities are, to a large extent, performed and interpreted as a gendered enterprise, and gender norms sanction his affects and reactions, especially when he fails and suffers. Moreover, this gendering applies not only to sexual situations and relationships to women, several examples of which we have noted but also to his troubles in other arenas, which are regularly conceived as markets. To follow up on my former analysis, I will give another three examples to underpin this view-one from the food market, one from the lodging market, and one from the publishing market.

The first person that Hamsun's man encounters while strolling hungrily in the street is a woman outside the butcher shop. He describes her extremely selectively: "She had only a single tooth in the front of her mouth" (p. 6) [Hun havde blot én Tand i Formunden (p. 6)]; and her eyes are "full of sausage" (p. 7) [fuldt af Pølse (p. 7)]. His empty stomach clearly governs his perception of her, and as a projection of his pain the woman even enlarges his hunger. She not only has, but is what he wants, and his grievance and anger are fuelled by this gendered piece of meat.

A similar procedure takes place in his relationship to his matron in Vaterland, whose power to kick him out of his lodgings strongly influences his description of her. When she asks him to move out, he sees her "pregnant belly bulging out toward me" (p. 198) [hendes store, frugtsommelige Mave strutted ud imod mig (p. 303)], and when she finally threatens him with the police, he contemplates "the most awful bloodshed, a blow that would strike her dead instantly, a kick in the belly" (p. 205) [den værste Blodsudgydelse, et Tryk, som kunde lægge hende død paa Stedet, et Spark i Maven (p. 314)]. The landlady's pregnancy functions as a sign of her threatening position vis-à-vis the moneyless tenant and connotes the economic power she has over him.

In contrast to earlier parts of the novel, the I-person in this last critical period of his stay in Kristiania, which ends with his departure, discloses to the reader what he is writing about. The more desperately distressed he is, the more he focuses on a grotesque female character, whose monstrosity makes his brain swollen. He imagines the woman as a "gorgeous fanatical whore who had sinned in the temple" (p. 187) [herlig fanatisk Skøge, der havde syndet i Templet (p. 284)], and he elaborates on how she would be intolerable to look at: "Her body was to be misshapen and repulsive: tall, very skinny and rather dark, with long legs that showed through her skirts with every step she took. She would also have big, protruding ears" (p. 187) [Hendes Krop skulde være mangelfuld og frastøtende: høj, meget mager og en Smule mørk, og naar hun gik, vilde hendes lange Ben komme til at skinde igennem hendes Skørter for hvert Skridt hun tog. Hun skulde ogsaa have store udstaaende Ører (pp. 284-859)]. However, most of all, he is interested in her "shamelessness, the desperate excess of premeditated sin that she had committed" (p. 187) [skamløshed, dette desperate Topmaal af overlagt Synd, som hun havde begaaet (p. 285)].

Clearly, he alludes to misogynist myths of a mixed female monster and femme fatale, which both circulated frequently in European fin-de-siècle culture. ${ }^{18}$ A more specific and plausible reason for

18 Idols of Perversity (Dijkstra [1986] 1988). 
why she occurs so manifestly in his writings at this very moment, is-combined with the lodging problematic - that his many refused texts and his troubles with being recognised by the publishers exclude him from the book and paper market. The imagination of an evil and repulsive woman mirrors his disappointment and desperation and shows how he utilises feminised images of horror to reflect his pain. Phantasies of the destructive woman, her eroticism and fertility are mainstream images that he invokes when he stares against the wall, but simultaneously they work both as projections of his failure and as reminders of the current gender hierarchy. When he is at the bottom of all, an even lower creature helps comfort his ego.

Sandel's Alberta and Freedom constructs an urban space from the point of view of a woman who only step by step recognises her ability to write. Coming from an urban bourgeois home in Norway, she attempts to make a living in the artisan life of Paris. Alberta's situation is profoundly governed by gender norms, which are reflected not only in the responses and sanctions she encounters in social life, but also in her low self-esteem. Unlike that of Hamsun's man, Alberta's struggle concerns overcoming the gendered, internalised barriers that frame her life. When she fails and suffers, her inclination is not like his-to attack the gendered counterpart with a subjugating evaluation, but instead to seek solidarity with other people. Following up on my former analysis, I will give two examples to support this view-one concerning a sense of relationship with the streetwalker and one concerning an exhibition of human others.

When posing for Mr. Digby, Alberta reluctantly feels related to other women in a similar situation, and she mentions models and streetwalkers in the same breath. "She understood the model who once, at Colarossi's, suddenly pulled a face at someone who had come in and just stood and stared. She understood the prostitute who hurls a contemptuous term of abuse in the face of the woman walking by. She felt an obscure solidarity with them" (p. 8) [Hun forstår den modellen som engang på Colarossi plutselig gjepte til noen, som kom inn og sto og så og ikke hadde foretatt seg noe annet enn å stå og se. Hun forstår gatepiken som kaster et foraktelig slengord i ansiktet på damen som går forbi. Dunkelt kjenner hun samfølelse med dem (p. 9)]. Sandel hints at the standard opinion that the work as a model was not respectable but could be associated with prostitution. Later in the novel, when Alberta visits an upper-class home together with her friend Veigaard, she in fact experiences being taken for a prostitute by the servants. "They thought I came from the street" (p. 123) [De tok meg for en fra gaten (p. 101)], she explains to her astonished companion. In the absence of the house owners, the servants politely, but decidedly refuse to offer the guests a meal. Extremely embarrassed because it is the home of his sister, Veigaard excuses the servants but is also angry because of their unexpected behaviour. Alberta, though, knows from the beginning that she is out of place; she instinctively foresees the outcome of the situation and ends up blaming herself.

When she is in desperate need of money later, she in fact considers taking to the street: "An old and evil thought reared its head, watchful as a poisonous reptile: I could go on the streets, earn ten francs, twenty francs, hide them in my stocking and earn more, I, as well as others. [ ... ] I could always be of use on the streets" (pp. 190-91) [En ond gammel tanke stikker hodet opp, påpasselig som et giftig kryp: Jeg kunne gå ut på gaten. Tjene ti francs, gjemme dem i strømpen og tjene flere, jeg så vel som andre [ ... ] på gaten duger jeg alltid (p. 156)]. However, she rejects the thought and instead accepts the support of Sivert, who offers to let her stay with him. With a powerful sense of shame and gratefulness, Alberta ends up modelling for Sivert, and her fight for freedom is ironically sealed with a relationship to a man whom she would never have considered a lover, and who even makes her dependent on him. In a gender perspective, this liaison is not surprising because it is realised according to the power of social norms, but at the same time, the narrative foregrounds Alberta's solidarity with her rescuer as a decisive motif of her choice.

Liesel's shocking abortion experience clearly works in favour of a positive conclusion when Alberta likewise is confronted with the question of whether she should give birth to a child. Another "push" in the same direction occurs when she and Sivert walk along the Boulevard Clichy and jump into a crowded tent "village", exhibiting, as a poster announces, "man-eating tribes from Central 
Africa" (p. 239) [menneskeetende stammer fra Afrikas indre (p. 195)]. Alberta insists on taking a closer look at these people, with whom she sympathises because they-with an echo from her own posing-must "put themselves on show" (p. 239) [stille seg til skue (p. 195)]. Obviously, the exhibition is organised as a Parisian happening to expose cultural difference and implicitly the inferior status of the Africans. The Western superior gaze certainly governs Alberta's perspective, but her dominating inclination is to feel pity because of their poverty and to recognise their condition of being exploited and out of place. Sivert's immediate response is to avoid the event-the place is crowded and smells bad-but soon he gets fascinated and picks up his drawing equipment. Alberta instead approaches a "Negress" (p. 240) [negerinne (p. 196)] who sits in a small tent with a baby by her breast. This woman understands Alberta's situation, smiles at her, and "something was released in Alberta's heart" (p. 241) [har noe løst seg i brystet (p. 197)]. Contrary to Sivert, who remains a distant outsider and purposefully makes use of the ethnic others for his artistic aims, Alberta identifies with the mother in the tent and ultimately decides to become one herself.

\section{Hungry Bodies and Attempts at Writing}

Both novels focus on the individual body and develop a modernist style that foregrounds the sensing subject's interaction with his or her surroundings. In the following, I will highlight similarities and differences in terms of how the novels depict the main characters' relationships to their own bodies, and accordingly interpret their phenomenologically founded aesthetics. ${ }^{19}$ From this point of view, I will discuss how the performativity of the body is part of the hero's literary ambitions (in Hamsun's case) and the heroine's more humble dream of a hidden talent (in Sandel's case).

The first-person narrative in Hunger makes the body appear as both a subject and an object, and the novel describes an almost endless variety of situations where the I-person senses and interprets his own body. ${ }^{20}$ In a scene in the first part (of four), the I-person is walking around in the Palace Park [Slottsparken], reflecting on why God has chosen exactly him for such a miserable life. He watches other people and finds their happiness expressed in their bodies: "no sign of grief in a single eye that I saw, no burden on any shoulder" (p. 15) [ikke Sorg i et eneste Øje, jeg saa, ingen Byrde på nogen Skulder (p. 25)]. Correspondingly, his own unhappiness is a bodily phenomenon: "My whole being was at this moment filled with the utmost anguish; even my arms ached, and I could barely endure carrying them in the usual way" (p. 16) [Mit hele Væsen var i dette Øjeblik i den højeste grad af Pine; jeg havde endog Smærter i Armene og kunde knapt holde ud at bære dem paa sædvanlig Maade (pp. 26-27)]. The pain is localised in his arms, which are perceived as detached from the torso. In the I-person's perception, the body is atomised and split apart, and these parts are even transformed into objects that must be carried instead of being carrying-subjects themselves. This tendency to see the body as an external and alienated object is a typical reaction, which underpins the view that perception as such is a main concern in the text. Another example is the continuation of the same scene, where he experiences troubles with his head:

"I had noticed distinctly that every time I went hungry for quite a long time it was as though my brain trickled quietly out of my head, leaving me empty. My head grew light and absent, I could no longer feel its weight on my shoulders, and I had the impression that my eyes showed a too wide stare when I looked at somebody" (p. 17).

19 By phenomenology, I understand a literary description of a subject that foregrounds the interpretation of his or her world from the perspective of a sensing body. For an instructive discussion of the influences from phenomenology (Beauvoir, Merleau-Ponty) on post-structuralist gender theory (Butler), see (Coole 2008).

20 The novel's tempus is primarily past tense but with many uses of present tense. This temporal arrangement produces a dynamic between the narrating ' $\mathrm{I}$ ' and the experiencing ' $\mathrm{I}$ ', a rhythm that sometimes visualises the distance between them and sometimes blurs it. While the sensing activity must be tied to the experiencing subject, both the experiencing and the narrating subject are interpreting their perceptions. 
[Jeg havde saa tydelig mærket, at naar jeg sulted lidt længe ad Gangen, var det ligesom min Hjærne randt mig ganske stille ud af Hovedet og gjorde mig tom. Mit Hoved blev let og fraværende, jeg følte ikke længer dets Tyngde paa mine Skuldre, og jeg havde en Fornæmmelse af, at mine Øjne glante altfor vidaabent, naar jeg saa paa nogen (p. 27).]

To describe hunger as an experience that makes the brain pour out, leaving the head empty and light, is a body-centred description of a failing intellectual and creative capacity, but it also aligns the body with a thing. Here, we can observe that he not only senses what his eyes can see, but also what they look like. In this way, the different body parts are made autonomous and partly reified, and their functions as necessary instruments for perception and thinking attract his interest more than their phenomenal referents do.

The head as a physical centre for his nervousness and God's responsibility for his humiliating condition get a very concrete description in a vision where all metaphysics is blown away:

"God had stuck his finger down into the network of my nerves and gently, quite casually, brought a little confusion among the threads. And God had withdrawn his finger and behold!- - there were fibres and delicate filaments on his finger from the threads of my nerves. In addition, there was a gaping hole after his finger, which was God's finger, and wounds in my brain from the track of his finger" (p. 17).

[Gud havde stukket sin Finger ned i mit Nervenet og lempeligt, ganske løseligt bragt lidt Uorden i Traadene. Og Gud havde trukket sin Finger tilbage, og der var Trevler og fine Rodtraade paa Fingeren af mine Nervers Traade. Og der var et aabent Hul efter hans Finger, som var Guds Finger, og Saar i min Hjærne efter hans Fingers Veje (p. 29).]

God works as a surgeon, but instead of healing the brain, his operation leaves holes and traumas. The irony that strikes the Christian childhood understanding is distinct, but first and foremost we notice a kind of de-souling taking place, both of the divine authority and of the human consciousness, leaving pure physiology and a de-animated body.

Soon after, he lies on a bench and seemingly recovers his ideas and thoughts, but the text dwells instead upon the way in which he looks at his own body: "As I lie there in this position, letting my eyes wander down my breast and legs, I notice the twitching motion made by my foot at each beat of my pulse" (p. 18) [Idet jeg ligger i denne Stilling og lader Øjnene løbe nedad mit Bryst og mine Ben, lægger jeg Mærke til den sprættende Bevægelse, min Fod gør, hver Gang Pulsen slaar (p. 31)]. He notices a foot that seems to move on its own and is encouraged by the sight. It is as though he "had met a good friend or got back a torn-off part of me: a feeling of recognition trembles through all my senses, tears spring to my eyes, and I perceive my shoes as a softly murmuring tune coming toward me" (p. 18) [havde truffet en god Bekendt eller faaet en løsreven Part af mig selv tilbage; en Genkendelsesfølelse sittrer gennem mine Sandser, Taarerne kommer mig i Øjnene (p. 31)]. In the very moment he thinks he has retrieved his creativity, he seemingly perceives a reunion of his body parts. In his consciousness, the fragmented body relates to alienation and failing intellectual capacity, and the complete body, inversely, to recognition and creativity.

However now he is caught by an opposite irony because his body is synecdochically represented by a pair of shoes:

"Then I begin, as though I'd never seen my shoes before, to study their appearance, their mimicry when I move my feet, their shape and the worn uppers, and I discover that their wrinkles and their white seams give them an expression, lend them a physiognomy. Something of my own nature had entered into these shoes-they affected me like a breath upon my being, a living, breathing part of me" (p. 19).

[Som om jeg aldrig havde set mine Sko før, giver jeg mig til at studere deres Udseende, deres Mimik, naar jeg rørte paa Foden, deres Form og de slidte Overdele, og jeg opdager, at deres 
Rynker og hvide Sømmer giver dem Udtryk, meddeler dem Fysiognomi. Der var noget af mit eget Væsen gaaet over i disse Sko, de virked paa mig som en Aande mot mit Jeg, en pustende Del af mig selv (pp. 31-32).]

Instead of regaining unification of body and soul, of experiencing the body as complete and vigorous, he must accept that the cerebral matter has left his head and now seems to occupy his shoes. Ironically, God has emptied his head of soul and instead animated his shoes.

As these examples show, the I-person's sensing is an important topic in Hunger. Through sense descriptions, the novel explores its main character's relationship with his surroundings. Sight, sound, smell, taste and touch govern the man's activities and stimulate his thoughts and actions. However, the perceptions are never pure or neutral, but fundamentally based on his physical condition, which allows him to read the world from a hungry stomach's point of view.

This material focus guides the creativity topic as well. Thus, as a point of departure, the writing is introduced as a way of making a living in the commercial market. "And indeed, when I was lucky and it turned out well, I would occasionally get five kroner for an afternoon's work" (p. 5) [Nu og da, naar Lykken var god, kunde jeg drive det til at faa fem Kroner af et eller andet Blad for en Føljeton (p. 2)]. After a while, however, this practical aim is met and overruled by an ambition of achieving social importance and artistic recognition. Slowly, the idea surfaces that writing is a spiritually inspired activity, and our hero concludes eventually that the divine spirit will help him produce a work of genius. After a successful act of writing he exclaims: "It's God! It's God' I cried to myself, and I wept from enthusiasm over my own words;" (p. 30) [Det er Gud! det er Gud! raabte jeg til mig selv, og jeg græd af Begejstring over mine egne Ord (p. 53)]. At the same time however, this romantic-metaphysical understanding of the enigma of inspiration is immediately unseated as he reminds himself of his trivial surroundings: "every now and then I had to stop and listen for a moment, in case someone should be on the stairs" (p. 30) [ ... nu og da maatte jeg standse op og lytte et Øjeblik om der skulde komme nogen i Trapperne (p. 53)]. As a parallel to this development, though, the result is increasingly poorer until he gives up his writing effort in the end.

Hence, art in Hunger is described on the one hand as an almost industrial process with the sole intention of earning money, and as a unique endeavour in the service of and created by divine inspiration on the other. The novel's irony-and ambiguity-may be identified as a deconstruction of both positions, leaving the most pertinent reading to emphasise its body aesthetics. The body's situation has a lasting influence on the creativity of the ambitious.

The scene introducing Alberta in Sandel's novel not only describes the model's feeling of being an object of other people's watching and the exposure of her naked body; it also shows how she directs her eyes at her own body. Reflected in a mirror, Alberta can examine her body from the outside:

"She could see her body in the long mirror, thin and lithe, clad in spare, lean muscles which arched and curved a little here and there, not much, not more than fitting. A controlled nakedness, without exaggeration, without any crass stamp of gender. If she had to be a woman, she could not very well demand to be encumbered with less (p. 6)."

[I det store speilet ser hun seg selv, tynn og lang i linjene, kledd i knappe, magre muskler, som buer og runder seg litt hist og her, ikke meget, ikke mer enn at en kan være det bekjent. En behersket nakenhet, uten overdrivelser, uten krast preg av kjønn. Når en først er et kvinnemenneske, kan en ikke godt forlange å være beheftet med mindre (p. 8)].

In her own estimation, her body is all right. She is satisfactory, neither too much nor too little body, neither too much nor too little woman. To Alberta, her body's exterior is not a problem. Her problem is the inner body, the one that walks around with invisible and undefined longings-longings that are metaphorically called "absorption" [sug] or "hunger" [sult]. This longing is something both in the body and something that can be measured by it, which is why the sensing body becomes such an important element of the novel's aesthetics. Time, for instance, materialises physically as a bodily 
experience. Already in the first scene, time is described as something that begins "to creep painfully forward in the way Alberta remembers from her childhood" (p. 5) [krype på den vonde måten Alberte husker fra barn (p. 7)]. Posing on the model's stand, the physically felt time reminds her of the way time would creep in the church and of the silent walks with her Dad. "She could sense physically how it crowded slowly past her, tenacious, absorptive, exhausting, how it could be heard and felt" (pp. 5-6) [Rent legemlig sanser hun hvordan den langsomt stimer forbi henne, seig, sugende, mattende, den bade høres og føles (p. 7)]. Alberta's body becomes a time measurer, a device where temporal experiences make their imprints. Her sense of time is therefore fundamentally anchored in the body, which experiences, archives and recollects events.

The absorptive body operates between past and present and shapes a pattern where childhood memories are used as a frame of interpretation of current events. Memories tend to fill in gaps and provide explanations, either confirmative or contrastive, of those moments in Alberta's life that unfold as bodily experiences and conditions. Being hungry may from this perspective have different meanings, such as grabbing some food after skiing or quieting a sudden appetite in haste because it takes too long until the meal is served. This kind of hunger can be satisfied. In her simple room in Paris, things are different, and even after Alberta has had some tea, biscuits and marmalade, she is still hungry. "Hungry? Yes ... " (p. 12) [Sulten? Ja-(p. 13)]. However not hungry in the same way as that time in her childhood. "No-now there was the eternal dissatisfaction of the body, which remained after she had eaten, which could not be quieted, only deadened and diverted. With tea, for instance, and cigarettes" (p. 12) [Nei-en kroppens evige utilfredshet, som er der også når en har spist. Som ikke kan stilles, bare døves og avledes. Med te for eksempel og sigaretter (p. 13)].

This incongruence between inner longings and outer appearance strikes her as strange. On the wall above the grate, there is a mirror in which she observes a person who does not quite fit to her inner ego. She sees "the contours of the unknown girl she meets in the mirrors wherever she settles down, a figure she would never be rid of and never understand, never quite succeed in aligning with her inner self" (pp. 29-30) [konturene av den ukjente, som hun treffer igjen i speilene, hvor hun så oppslår sin bopel, en fremtoning hun aldri blir kvitt og aldri blir klok på, aldri riktig får til å rime med sitt indre menneske (pp. 26-27)]. Alberta's inner self works as an inert memory, while her outer, experiencing self continually negotiates with the present surroundings and remembered past. For instance, the adult woman's worries about money, debt, loneliness and longing are metaphorically called an "empty paralysis" (p. 172) [tom lammelse (p. 142)] that spreads into her arms and hands and are compared to worries that ride a child "before the skin has formed on its soul" (p. 173) [uten ferdig hud på sjelen (p. 142)]. After the loss of her friend Veigaard, who dies in a car crash, she is knocked out by a pain that she hardly manages to live with, and she is reminded of the earlier loss of her parents in an accident. Having reached rock bottom, she is numbed; even the pain is gone. "All that is left is a calcification in the mind, a hard scar, that cannot be affected again" (p. 173) [Alt som er igjen av den, er en forkalkning i sinnet, et hardt arr, som ikke kan angripes mer" (p. 142)]. In this way of responding to suffering, we can recognise a mental pattern in Alberta, whose hungry and absorptive body in Sandel's modernist aesthetics becomes a language for loss, longing and unsatisfied desires.

Verbal images of the body in a variety of situations saturate the text, but unlike Hamsun's body, which tends to fall apart and let the members operate on their own, Sandel's body is complete and functions as a membrane between the inner and outer self. While Hamsun's man lives in the present and negotiates through the city, confronted with numerous projections of his hunger, Sandel's woman carries her past with her and interprets bodily experiences in the frame of memories. Prompted by material deficiencies, her hunger is predominantly caused by unfulfilled longings and intervening memories. Both novels stage a hungry person whose hunger is complete with a surplus of meaning.

At the beginning, Alberta has no writing ambitions, but her writing is a main theme through the novel. Like Hamsun's man she initially writes in order to earn some money and has no expectations whatsoever. On the contrary, her writing is described as a work done "with reluctance and shame" (p. 32) [med uvilje og skamfølelse (p. 28)]. At the same time, she writes other things, too, something 
"different" (p. 32) [annerledes (p. 28)], but those pieces are useless and nothing she can submit to a paper. The writing practice is only a "form of idling" (p. 32) [form for lediggang (p. 28)]. Sometimes she destroys her texts, but mostly she hides them in a suitcase; she has a miserable weakness for this nightly endeavour. Slowly, she begins thinking that these fragments may be put together to make up something comprehensive, thus she finds the courage and self-conscience to go on writing.

Similar to Hamsun's man, Alberta has an inner drive to write, but unlike him, it takes more time for her to believe in her talent. Similar to him, she is unable to create during periods when the material and mental circumstances are too daunting, but unlike him, she blames herself instead of fighting real obstacles and phantasised demons. While Hamsun's man in the end flees the city and seemingly gives up his writing, Sandel's woman appears certain about something that could perhaps become literature.

Hamsun's novel ends with a hero who escapes from the city and renounces his writing ambitions, leaving the reader uncertain about the result of his efforts. His response to the city, where his spiritual claims have been met by material poverty and a hungry body, is to turn his back on everything for the time being. Sandel's novel instead ends in a harmonising gesture from Alberta to Sivert, wherein they agree to accept the child and stay together. She has found, at least impermanently, a haven where the loving and reproductive part of her identity has become an answer; she is satisfied because her writing project remains latently fertile and has not been abandoned.

\section{Conclusions}

Both novels show that the modern subject in city space is gendered-and gendered differently. Both characters, Hamsun's man and Sandel's woman, construct their urban surroundings through a gendered gaze and are themselves constructed as man and woman in a social and cultural setting. Moreover, the novels also show how this process takes place within a context of normativity, implying that gender norms are revealed as the premises of the performative subjects' frames of action.

Even though the novels are published more than forty years apart and take place in different cities, they have some structural traits in common when it comes to gender norms. Hamsun's man experiences humiliation when lacking economic means, the correct attire, food, lodgings, masculine attraction, sex appeal, and success as an author. All these weaknesses threaten to feminise him, thus revealing that femininity is a norm that is constructed as inferior and therefore something against which he must fight. Concurrently, these norms help him construct an enemy-a female other-who is even more inferior than him. The feminised imagery of the novel-femme fatale, monster, prostitute, etc.-discloses how these misogynist myths look, and the man's struggle in the modern city truly explains why they continue to work.

Sandel's Alberta experiences being the inferior feminine. Her existence in the modern urban space is a constant struggle, not only due to poverty but also due to a position of being degraded and precariously exposed to the male gaze and its dominating power. Not only does her work as a nude model make her extremely exposed to devaluating judgements, but her normal appearance as a poor woman also implies-according to cultural norms-that she is inferior, on the edge of being the worst of all, a prostitute. To Alberta there is no superior masculine position available, and to the extent that she assesses her male friends and acquaintances, she does so by means of irony. Thus, she walks through the city in search of other individuals in inferior positions with whom she can find solidarity. The palette of female friends with similar experiences underscores the novel's inter-subjective intentions and foregrounds a kind of solidarity, if not intimacy, between the women.

To both protagonists, inferior femininity is a constant option and threat, but their responses and actions are different. The strategy of the male subject in Hunger is to fight his way up from humiliation by humiliating the female other; the strategy of the female subject in Alberta and Freedom is instead to seek solidarity with persons who have experiences similar to her own.

Hamsun's man and Sandel's woman both perceive their own bodies as crucial to the interpretation of their physical surroundings. But while the hero in Hunger must deal with a body falling apart and a confrontation with the world that depends on a totally fragmented bodily experience, the heroine 
in Alberta and Freedom instead sees herself as a body divided between outer appearance and inner inclinations. He chooses to leave the scene in a preliminary insight of having lost any opportunity, while she stays and presumably chooses a harmonious family life.

Both novels stage a person with writing proclivities in a city setting where the success or failure of artistic work is subjected to the mechanisms of a market economy. Their artistic ambitions are to a large extent decided by their material conditions, which seem to manipulate Hamsun's hero out of the whole business, and Sandel's heroine to stay calm and not give up. The gender aspect of these choices is to see Hamsun's man's escape as analogous to his failure to connect with possible acquaintances, while Sandel's woman's staying could be read as analogous to her ability to connect with other people. In common is the belief in the body's basis as a denominator for the perception and interpretation of sensual and cognitive impressions of the world.

Funding: This research received no external funding.

Conflicts of Interest: The author declares no conflict of interest.

\section{References}

Baudelaire, Charles. 1964. The Painter of Modern Life. New York: Da Capo Press. First published 1863.

Benjamin, Walter. 2006. The Writer of Modern Life. Essays on Charles Baudelaire. Edited by Michael W. Jennings. Cambridge and London: Harvard University Press.

Brynhildsvoll, Knut. 1998. Sult, sprell og altmulig. Alte und neue Studien zu Knut Hamsuns antipsychologischer Romankunst. Frankfurt am Main: Peter Lang Verlag.

Butler, Judith. 1999. Gender Trouble. Feminism and the Subversion of Identity. New York and London: Routledge. First published 1990.

Butler, Judith. 1993. Bodies that Matter. On the Discursive Limits of 'Sex'. New York and London: Routledge.

Coole, Diana. 2008. Butler's Phenomenological Existentialism. In Judith Butler's Precarious Politics. Critical Encounters. Edited by Terrell Carver and Samuel A. Chambers. New York and London: Routledge.

Dijkstra, Bram. 1988. Idols of Perversity. Fantasies of Feminine Evil in Fin-de-Siècle Culture. New York and Oxford: Oxford University Press. First published 1986.

Felski, Rita. 1995. The Gender of Modernity. Cambridge and London: Harvard University Press.

Hamsun, Knut. 1890. Sult. København: Philipsen forlag.

Hamsun, Knut. 1994a. Fra det ubevidste sjeleliv. Artikler om litteratur. Oslo: Gyldendal.

Hamsun, Knut. 1994b. From the Unconscious Life of the Human Mind. Translated by Marie Skramstad De Forest. Louisville, Kentucky: White Field Press.

Hamsun, Knut. 2016. Hunger. Translated by Sverre Lyngstad. Edinburgh and London: Canongate.

Humpál, Martin. 1998. The Roots of Modernist Narrative: Knut Hamsun's Novels Hunger, Mysteries, and Pan. Oslo: Solum forlag.

Joyce, James. 1972. Ulysses. London: Edward Arnold. First published 1924.

Kirkegaard, Peter. 1975. Knut Hamsun som modernist. København: Medusa forlag.

Langås, Unni. 2004. Kroppens betydning i norsk litteratur. Bergen: Fagbokforlaget.

Langås, Unni. 2014. Beholde barnet? Faser i abortens litterære og juridiske historie. In Litteratur och lag. Skandinavisk kultur och litteratur i ett internationellt och toürvetenskapligt perspektiv. Riga: Acta Universitatis Latviensis, Volume 799.

Mæleng, Per. 1994. Fysiognomier. Kommentar til kroppen som skriftens scene. Lesning av Knut Hamsuns Sult. In Edda. Scandinavian Journal of Literary Research 2. Oslo: Universitetsforlaget.

Parsons, L. Deborah. 2000. Streetwalking the Metropolis: Women, the City, and Modernity. Oxford: Oxford University Press.

Paulson, Sarah J. 2005. Alberte og Paris. Erfaringen av det moderne. In Edda. Scandinavian Journal of Literary Research 1. Oslo: Universitetsforlaget.

Pollock, Griselda. 1988. Vision and Difference: Femininity, Feminism and Histories of Art. London: Routledge.

Rees, Ellen. 2010. Figurative Space in the Novels of Cora Sandel. Bergen: Alvheim \& Eide Akademisk Forlag.

Sandel, Cora. 1926. Alberte og Jakob. Oslo: Gyldendal Norsk Forlag.

Sandel, Cora. 1976. Alberte og Friheten. Oslo: Gyldendal Norsk Forlag. First published 1931. 
Sandel, Cora. 1984. Alberta and Freedom. Translated by Elizabeth Rokkan. Athens and Ohio: Ohio University Press. First published 1963.

Sandel, Cora. 1939. Bare Alberte. Oslo: Gyldendal Norsk Forlag.

Selboe, Tone. 2003. Litterære vaganter. Byens betydning hos seks kvinnelige forfattere. Oslo: Pax Forlag A/S.

Stounbjerg, Per. 1990. Modernitetens ånd er kvinnelig. Sammentænkningen af smuds, modernitet og kvindelighed omkring år. Oslo: Profil. First published 1985.

Witt-Brattström, Ebba, ed. 2004. The New Woman and the Aesthetic Opening: Unlocking Gender in Twentieth-Century Texts. Huddinge: Södertörns Högskola.

Woolf, Virginia. 2000. Mrs. Dalloway. Oxford: Oxford University Press. First published 1925.

2018 by the author. Licensee MDPI, Basel, Switzerland. This article is an open access article distributed under the terms and conditions of the Creative Commons Attribution (CC BY) license (http://creativecommons.org/licenses/by/4.0/). 